\title{
Imaging Stuart Family Politics: Dynastic Crisis and Continuity
}

Review Number: 2292

Publish date: Thursday, 15 November, 2018

Author: Catriona Murray

ISBN: 978-1472424051

Date of Publication: 2017

Price: $£ 115.00$

Pages: 202pp.

Publisher: Routledge

Publisher url: https://www.routledge.com/Imaging-Stuart-Family-Politics-Dynastic-Crisis-andContinuity/Murray/p/book/9781472424051

Place of Publication: London

Reviewer: Jemma Field

Catriona Murray's Imaging Stuart Family Politics is an impressive book, both for its high level of original research, and for its balance of academic sophistication with accessibility. Cross-disciplinary in approach, Murray employs contemporary visual and textual evidence in her exploration of the political value of the culture that surrounded royal procreation and premature loss in Stuart Britain. Within this, she is to be commended for the focus on print culture (rather than the 'fine arts') which, as a responsive, accessible, and widespread medium, allows her to extend the argument to the Stuart public audience. It is important to try to ascertain the intentions of a monarch, but it is equally valuable - and sometimes more so - to gain insight into the effect of those messages; how they were received and understood, or, indeed, misunderstood. In this book, Murray does both. Rather than analysing the images in isolation, or from a solely formal perspective, Murray carefully locates them within the socio-political and physical context, whereby consideration is given to influential elements of audience and display that impacted on the meaning and changed over time.

The chronology of the book - focussing on the Stuart dynasty in England from King James VI and I through to Queen Anne - allows Murray scope to isolate patterns across the centuries and to determine those features that were unique to each individual familial set. As a result, invaluable consistencies in the ceremonial and display associated with childbirth, baptism, and burial are uncovered, but they are set alongside a rich discussion of the impact that was wielded by the changing political and religious climate. Thus, the monarchy as an institution was not monolithic or immutable, but cognisant of context and capable of flexibility, forgoing tradition and precedence if they were not appropriate to the context. One such example that Murray discusses is King Charles I's decision to refrain from a public baptismal celebration in favour of private, domestic ceremony for his third son, Prince Henry, Duke of Gloucester. This, Murray argues, was directly related to the religious controversy of the Second Bishops' War and the desire to shield the occasion 'from the scrutiny of the King's detractors' (p. 25), in order to avoid accusations of popery that could arise from the use of High Church ritual. Wisely though, Murray's book takes a thematic rather than chronological approach. The first two chapters - on the celebrations surrounding pregnancy, birth, and baptism, and then on the visual and literary shaping of young heirs apparent - provide a firm grounding in the politics of dynasty. Murray shows the use of reproductive imagery and princely representations to have been critical to building subject loyalty and support, but they could also be potentially destabilising for the 
current ruler. It is against this reading that the later discussions of the political and personal repercussions of premature royal death are set.

As is now very well-known, perhaps thanks in large part to the famous struggles of the Tudors, for the British monarchy, as for their European contemporaries, the preservation and longevity of the dynasty was of paramount importance. The birth of the heir, and preferably more than one 'spare', was the treasured key to dynastic security while the birth of daughters spelled the proliferation of important networks and alliances, and, in some cases, even territorial and financial gain. The political benefit of royal children, should it ever have been in doubt, was categorically articulated by King James himself who, writing to congratulate his brother-in-law King Christian IV on the birth of his son, stated:

we are moved both for your sake and the sake of the kingdom itself, over which you are ruling; because as children are a source of solace to parents, thus are they a source of support for kings; for the more children there are, the deeper are the roots and the more numerous are the supports, upon which the stability of a kingdom rests.'[1] [2]

Considering the political and dynastic weight of royal children, Murray's investigation of the images (in multiple media) that proliferated around the loss of these precious 'supports' is a welcome addition to the growing field of work that investigates and uncovers the central facets of dynastic strength and identity, as well as the flexibility of memories and ideologies. For, as Murray elaborates throughout the book, the early death of a prince could be used to bolster public support for the monarchy as royal family and nation were united in a shared grief and were equally invested in the accompanying visual and textual narratives of loss and commemoration. Yet, on the other hand, the loss of royal progeny also gave cause for reproductive and memorial imagery to be used to critique the current ruler and policy, as those very same narratives became potent eulogies for the promised (infinitely better) reign that the nation had lost.

A significant part of Murray's book forcefully reiterates that the foundational role of the royal woman queens consort and regnant - was to produce heirs and secure the succession. This focus is a favourable contribution to publications on the nature of female consortship, such as those ground-breaking texts by Clarissa Campbell-Orr and the more recent HERA-funded project Marrying Culture: Queens Consort and European Identities 1500-1800, which has recently started to publish their findings.[2] [3] A real strength of Murray's book however, is that she extends the 'succession question' beyond the walls of the monarchy. As she rightly argues, the question of the provision of heirs was clear-cut for the monarchy (they wanted them), but it was a much more contentious and variable question for royal subjects, whereby both royal infertility and fecundity could be sources of widespread anxiety. Perhaps most pointedly, in the aftermath of Catherine of Braganza's inability to provide King Charles II with a child, royal subjects in Britain and rulers on the continent watched with bated breath as the monarchy grappled with the possibility of a Catholic ruler that gave rise to the Exclusion Crisis. For the women themselves, this success or failure had significant repercussions for their own political value and popularity, both at court and among the broader populace.

Yet, while succession politics have long received scholarly attention, Murray adds to this body of literature by focussing on the female body and by providing a close analysis of the associated visual and written culture. Paintings and prints, pamphlets and poems, are unpacked to provide evidence of the ways in which royal women were visually conflated with concepts of fecundity, dynasty, and legitimacy. She further shows that this trope became so powerfully ingrained that even when childless, queens, such as Mary and Anne, were maternalised as mothers to the nation, which, although not explored by Murray, bears interesting comparison with the imagery associated with their Tudor predecessor, the Virgin Queen Elizabeth I. For Anne, in the aftermath of William, Duke of Gloucester's death, the queen 'embraced a language of symbolic maternity' that 'reinforced her figurative motherhood' (p. 104). Analysing those prints and paintings of consorts who did realise the reproductive aims of the Stuart dynasty - Anna of Denmark (consort of James VI and I) and Henrietta Maria (consort of Charles I) - Murray shows how these images used visual codes, compositional structure, and the manipulation of scale to proclaim legitimacy and bolster popularity. Yet she 
remains conscious of the limits of visual culture, reminding the reader of their finite abilities with statements such as 'ultimately, the messages promoted during baptismal celebrations could only endorse. Their powers to persuade were limited' (p. 28) or that 'at times of crisis, their [familial representations] facility for calming apprehensions was limited' (p. 140). Leading on from this, Murray shows how such imagery could be appropriated and subverted beyond the control of the court, thereby damaging the very monarchy that was supposed to be of benefit. Multiple examples of this are threaded throughout the book, but it is most potently borne out in the focus on how reproductive iconography was used to reduce the power of monarchical continuity (and legitimacy) when a rupture in lineal descent was brought about by the Glorious Revolution. Murray further examines how it could also be detrimental for those monarchs whose children did not survive infancy.

In her later chapters, Murray turns her attention to the images, monuments, and verse that proliferated around the premature death of several Stuart princes. Looking to official and popular commemorations, she argues that such a loss was devastating on a dynastic, domestic, and national scale. The decision therefore, to have small, reserved funerals, to not commission tomb monuments, or to not issue court mourning, were all deeply political acts that sought to reduce the new spotlight that had been cast onto the "vulnerability of hereditary succession' (p. 74). One of the central examples that Murray perceptively explores is King James's decision to stage an elaborate state funeral for his son, Henry, Prince of Wales, in 1612, but to forgo any permanent memorial monument. While this choice has been variously interpreted by scholars, Murray convincingly argues that its absence was firmly rooted in the desire to contain public memory and expectation, and to reduce the likelihood of future comparisons between himself and the lost 'luminary of the Stuart line' (p. 77).

Beyond the investigation of contemporary mourning imagery, Murray tracks the political use and value of posthumous portraiture decades - and even centuries - after the sitter had passed. These images, as she argues, encapsulated fond memories, dashed hopes, and the idealised expectations of a future that could have been, which implicitly critiqued the reigns and heirs that were. This was particularly apparent in the late years of the Queen Anne's heir-less reign, when prints were issued of a host of prematurely deceased Protestant princes extending back to the minority rule of King Edward VI in the mid-16th century. But, as Murray concludes, of all the prematurely deceased Stuart princes none could 'rival the sustained hold which Henry, Prince of Wales's image exerted over the public consciousness' (p. 146), a fact that in itself is testimony to the success of original procreative imagery. Then again, as Murray is always quick to point out, such enduring imagery also served to concurrently highlight the vulnerability of hereditary monarchy. Here was a prince unparalleled in virtue, military skill, Protestant piety, and majestic bearing who had not lived long enough to exercise these gifts on the international courtly stage, thereby depriving the kingdom of a golden age of decorous, sincerely Protestant, and martial yet judicious masculine rule. This continued well into the eighteenth century where the continued allure of nostalgic, posthumous portraits (literary and artistic) spoke volumes about persistent anxieties over the Stuart dynasty, and about the state and future of a hereditary British monarchy generally.

This book is a must-read for scholars of British court studies, dynastic politics, and portraiture, but it also holds marked interest and benefit for those interested in ritual and ceremonial, the role and rights of royal women, and the political power of posthumous imagery, memory, and nostalgia. It is a good model for emerging art historians, showing the advantages of an object-based approach that is cognisant of how images and texts were, so often, highly calculated responses to political and religious circumstance, and how audience reception and understanding can yield invaluable insights into socio-cultural beliefs, expectations, and anxieties. In addition, the style of prose is polished and refined, yet remains comprehensible to nonspecialists of art history, and the breadth of research and level of original thought ensures that this text will be long-favoured by historians more generally. There is little to critique in Murray's book, and while it would have been interesting to see her comparative approach extend to the ways in which contemporary European dynasties dealt with the political disaster of prematurely deceased princes, that would have made it an entirely different book. Indeed, it is safe to say that Imaging Stuart Family Politics achieves the author's aim of providing 'a new understanding of the mechanics of Stuart familial rhetoric, elucidating the important 
role played by visual and material culture in articulating this aspect of early modern politics' (p. 3).

[1] [4] The Royal Correspondence of King James I of England (and VI of Scotland) to his Royal Brother-inLaw, King Christian IV of Denmark, 1603-16, ed. Ronald M. Meldrum (Brighton, 1977), p. 11.

[2] [5] Queenship in Britain, 1660-1837: Royal Patronage, Court Culture and Dynastic Politics, ed. Clarissa Campbell-Orr (Manchester, 2002); Queenship in Europe 1660-1815: The Role of the Consort, ed. Clarissa Campbell-Orr (Cambridge, 2004); Queens Consort, Cultural Transfer and European Politics, c.1500-1800, ed. Adam Morton and Helen Watanabe-O’Kelly (London, 2017).

The author is happy to accept this review and thanks the reviewer for a rigorous and generous assessment.

Source URL:https://reviews.history.ac.uk/review/2292

\section{Links}

[1] https://reviews.history.ac.uk/item/298087

[2] https://uolonline-

my.sharepoint.com/personal/danny_millum_sas_ac_uk/Documents/Reviews/current\%20reviews\%20for\%20editing/ [3] https://uolonline-

my.sharepoint.com/personal/danny_millum_sas_ac_uk/Documents/Reviews/current\%20reviews\%20for\%20editing/ [4] https://uolonline-

my.sharepoint.com/personal/danny_millum_sas_ac_uk/Documents/Reviews/current\%20reviews\%20for\%20editing/ [5] https://uolonline-

my.sharepoint.com/personal/danny_millum_sas_ac_uk/Documents/Reviews/current\%20reviews\%20for\%20editing/ 